\section{Pleas for would-be emigrés}

SIR - We wish to draw your attention to the case of the respected Soviet cancer researcher, Dr Iosef Irlin, who has been involved in the fields of tumour virology and tumour immunology. His work has been of theoretical importance and in no way related to matters falling within any national security interests.

Dr Irlin applied four years ago for permission to emigrate with his family to Israel, to be reunited with other members of his family there, and he has reapplied repeatedly during the past four years. All his requests have been refused, without explanation. During this time, he has been without professional employment and his several applications for jobs have been rejected.

In an earlier letter, Dr Irlin states:

It is now four years that $I$ have been in refusal. As you must know well, being engaged in my profession, I have never been connected with any state secrets or security, dealing only with experimental oncovirology and immunology of experimental tumours - quite an open branch of science. In spite of this, my family and I were not allowed to emigrate to Israel and none of the officials, despite my numerous applications, took the trouble to give me any good ground for the refusal. By now, I repeat, for four years, I have been without a professional job and practically without hope. All my efforts to get any decent job have failed.

We appeal to scientists from all countries, including our Soviet colleagues, to use all their influence so that Dr Irlin, together with his family, is allowed to leave the Soviet Union to live and work in the country where he and his family wish to stay.

GEORGE KLEIN

JERZY EINHORN

Karolinska Hospital, Stockholm, Sweden

STUART A. AARONSON

National Cancer Institute, Bethesda, Maryland, USA

FRED RAPP

Pennsylvania State University, Hershey, Pennsylvania, USA

ANDRE LWOFF

Pasteur Institute, Paris, France

THOMAS GRAF

European Molecular Biology Laboratory, Heidelberg, FRG

DAVID BALTIMORE

Massachusetts Institute of Technology, Cambridge, Massachusetts, USA

ROGER WEIL

University of Geneva, Switzerland

SIR - I wish to support in the strongest possible way the appeal of Dr André Lwoff, and other Western biochemists and geneticists on behalf of Dr David Goldfarb whose exit visa for Israel has recently been withdrawn by the KGB (see Nature 308 , $679,766$ and 309,$104 ; 1984)$.

I have known and admired Dr Goldfarb since he came to work in my microbial genetics unit at Hammersmith Hospital, London, some twenty years ago, and respected him as among the most honest, able and innovative Soviet geneticists of the post-Lysenko era. To those of us who have known Dr Goldfarb well, he has always reflected credit on the Soviet Union for his work on microbial genetics. I therefore found his harassment by the KGB when he applied for an exit visa in 1979 not only unjust but incomprehensible, especially in view of the assertion by the Soviet Academy of Sciences that he knew no state secrets. He also demonstrated his courage and patriotism at the siege of Stalingrad where he lost a leg. The latest withdrawal of his visa, again approved by the Academy of Sciences, on the eve of his departure for Israel savours of paranoid persecution and causes great distress to his many friends abroad in view of his advancing years and poor health. I therefore hope, in the interests of all those who support goodwill and international collaboration in science, that Goldfarb's case will shortly be resolved in his favour.

WILLIAM HAYES

Department of Botany, Australian National University, Canberra, ACT 2601, Australia

\section{Skew physics}

SIR - I was struck by the remarks on Fritz London in your recent article (Nature 10 May, p.109). Amongst other qualities, London was gifted with modes of apprehension of physical problems that were skew, or at any rate out of line with those of his contemporaries, with the consequence that some of his publications at first lacked the full impact their importance warranted. As some compensation, his originality enabled him to grasp more confidently skew developments presented to him.

I was fortunate to have personal experience of this trait in relation to my earlier letter (Nature 132, 1002; 1933) on the change from "aromatic" to "metallic" electrons in organic compounds. This text was written with some unease because of its novelty, but on my walking back from posting it to your offices I was introduced to Fritz London by F.A. Lindemann, who was chatting with him at the entrance to the Old Clarendon Laboratory at Oxford. Rather tremulously, I showed them my letter. Lindemann read this politely, and said little, but Fritz London immediately grasped what it was trying to focus on about the unusual physical properties of aromatic molecules, such as their large diamagnetism, and reassured me. He himself later developed this theme more fully.

His kind of responsiveness raises the interesting educational problem of whether teachers may be justified in describing select skew approaches to physics to their pupils, not only to leave loose ends for innovative developments, but generally. It can be argued that the best informed financial patronage for research, and most valuable support for research programmes, is to be sought from managers and directors who understand a mixed conceptual language much more readily than would physicists with much stricter training in scientific communication.

A.R. UBBELOHDE

Department of Chemical Engineering and Chemical Technology,

Imperial College,

London SW7 2BY, UK

\section{Sea as dark as wine}

SIR - When Homer sang of the "winedark" sea (see Nature 303, 568, 1983; 307, $590 ; 309,204,1984)$ what he had in mind must surely have been its darkness, rather than the colour, and "dark as wine" might be a better translation. After all, one can say that "her eyes sparkled like diamonds", without implying that they were of the same colour.

Ionian Greeks knew all about wine, but with what other fluids would they have been familiar, to be compared in darkness with the sea? Blood would not have done, and the Homeric heroes had no use for ink, which was a muddy concoction available, if at all, only to scribes. So, gazing into the mysterious depths of a calm dark sea, how better could the poet then have described it, than with his simile of the transparent darkness of a full cup of wine?

C.B. GOODHART

Gonville \& Caius College,

Cambridge CB2 1TA, UK

\section{Luddites defended}

SIR - It has become fashionable to describe negative attitudes to technological change by making an analogy to the Luddites. Terms such as "neo-Luddite" or even

"latter-day Luddite" are appearing regularly. The most recent I have noted is in David Sills' review (Nature 10 May, p.185). p.185).

The term seems to imply a senseless denigration of new ideas, an attempt to retain the old. I would suggest that this is a gross generalization. It strikes me that the original Luddite leaders were more concerned with the terrifying effects that new technology was to have on the workforce. Whilst their methods of protecting people from unemployment, with its associated evils, were violent and destructive, their intentions were highly honourable and deserving of our attention today.

RICHARD MORRISH

Department of Computing Studies,

Institute of Catholic Education,

Ballarat Campus, PO Box 650 .

Ballarat 3350, Victoria,

Australia 